\title{
Placental Expression of Angiopoietin-1, Angiopoietin-2 and Tie-2 during Placental Development in an Ovine Model of Placental Insufficiency-Fetal Growth Restriction
}

\author{
AMY S. ERICKSON HAGEN, RYAN J. ORBUS, RANDALL B. WILKENING, TIMOTHY R.H. REGNAULT, AND \\ RUSSELL V. ANTHONY \\ Department of Biomedical Sciences [A.S.E.H., R.J.O., R.V.A.], Colorado State University, Fort Collins, \\ CO, 80523; Department of Pediatrics [R.B.W., T.R.H.R., R.V.A.], University of Colorado Health Sciences \\ Center, Aurora, CO 80045
}

\begin{abstract}
ABS
Fetal growth restriction (FGR) is associated with increased
perinatal morbidity and mortality, and often results from func-
tional placental insufficiency. Placentation requires extensive
vasculogenesis and subsequent angiogenesis, in both maternal
and fetal tissues. Angiopoietin-1 (Ang-1) and Angiopoietin-2
(Ang-2) are angiogenic growth factors expressed in the placenta,
and compete for binding to a common receptor, Tunica interna
endothelial cell kinase-2 (Tie-2). Our objective was to examine
Ang-1, Ang-2 and Tie-2 expression in ovine placental tissue
obtained from normal and FGR pregnancies throughout gesta-
tion. Fetal cotyledon and maternal caruncle tissue concentrations
of Ang-1, Ang-2 and Tie-2 mRNA were assessed by real-time
reverse transcriptase-polymerase chain reaction and protein con-
centrations were assessed by Western immunoblot analysis, at
55,90 and 135 d gestational age (dGA). Concentrations of Ang-1,
Ang-2 and Tie-2 mRNA in FGR fetal cotyledons were increased at
55 dGA, and Tie-2 mRNA concentrations were decreased in FGR
fetal cotyledons and maternal caruncles at 135 dGA. Immunoblot
analysis demonstrated increased concentrations of Ang-2 in the fetal
\end{abstract}
The placenta is a multifaceted organ that plays the critical role of maintaining and protecting the developing fetus. A number of placental structural abnormalities have been associated with fetal growth restriction (FGR), including a decrease in villous number, diameter and surface area, as well as a decrease in arterial number, lumen size and branching (1-6). All of these abnormalities can adversely affect placental function, and ultimately deprive the fetus of the nutrients required for optimal growth. Although a variety of factors contribute to

Received January 24, 2005; accepted May 31, 2005.

Correspondence: Russell V. Anthony, Ph.D., Department of Biomedical Sciences, ARBL-Foothills Campus, 3801 West Rampart Road, Colorado State University, Fort Collins, CO 80523-1683; email: Russ.Anthony@Colostate.edu

This work was supported in part by the National Institutes of Health (HD 20761) and the College of Veterinary Medicine and Biomedical Sciences Research Council.

DOI: 10.1203/01.pdr.0000185266.23265.87 cotyledon at $55 \mathrm{dGA}$, and lower concentrations at $135 \mathrm{dGA}$. In contrast, concentrations of Tie-2 were increased at $90 \mathrm{dGA}$, but tended to decrease at $135 \mathrm{dGA}$ in FGR maternal caruncles. The changes observed during early- to mid-gestation may result in increased branching angiogenesis, but may also set the stage for increased nonbranching angiogenesis during late gestation, altered placental architecture and placental insufficiency that result in FGR. (Pediatr Res 58: 1228-1232, 2005)

Ang, angiopoietin
dGA, days gestational age
FGR, fetal growth restriction
HT, hyperthermia
RT-PCR, reverse transcription-polymerase chain reaction
Tie, tunica interna endothelial cell kinase
TN, thermoneutral
VEGF, vascular endothelial growth factor

a healthy placenta, placental villi form in conjunction with the developing placental vasculature, thereby providing the main unit for nutrient exchange (7).

Various approaches have been used to generate animal models of FGR in several species, including sheep (8). While placenta in sheep are divided into many discreet attachment sites or placentomes, within each placentome the villous tree is structurally similar to that which occurs in the human, as both can be divided into stem, intermediate and terminal villi $(9,10)$. In our model, pregnant ewes are exposed to high ambient temperature starting on day 40 of a $\approx 147 \mathrm{~d}$ gestation, and remain in this environment for approximately $80 \mathrm{~d}$, resulting in reductions of placental and fetal weights (12) of approximately $51 \%$ and $42 \%$, respectively, near term (135 d gestational age; dGA). Furthermore, these near term pregnancies exhibit fetal hypoxia, hypoglycemia, reduced umbilical blood flow, increased fetal sys- 
temic blood pressure and elevated placental vascular resistance $(8,12,13)$, the latter being indicative of altered placental vascular architecture (4). Previously $(11,12)$, we determined that expression of vascular endothelial growth factor (VEGF), placental growth factor (PlGF), and their receptors (VEGFR-1 and VEGFR-2) is altered in a gestational age-dependent fashion in these ovine FGR pregnancies, such that changes that occur during early- to mid-pregnancy are not mirrored in late gestation. While the angiopoietins (Ang-1 and Ang-2) are not part of the VEGF family, they act to potentiate the actions of VEGF. Both Ang-1 and Ang-2 act through their common receptor, Tunica interna endothelial cell kinase 2 (Tie-2; 14); however, while Ang-1 acts synergistically with VEGF to simulate angiogenesis (15) by inducing maturation and stabilization of developing vasculature (16), Ang-2 causes destabilization required for sprout formation and branching angiogenesis (14). Therefore, our objective was to examine the expression of Ang-1, Ang-2 and Tie-2 at three gestational ages in our ovine model of FGR.

\section{METHODS}

Experimental animals. Singleton Columbia-Rambouillet ewes approximately 2 to $3 \mathrm{y}$, at $40 \mathrm{dGA}$, were placed in either thermoneutral (TN) or hyperthermic (HT) environments. The TN environment kept a constant ambient temperature of $20 \pm 2{ }^{\circ} \mathrm{C}$ and relative humidity of $30 \% 24 \mathrm{~h}$ per day. The HT treatment chamber (Bainbridge, Marcellus, MI) controlled ambient temperature of $40^{\circ} \mathrm{C} 12 \mathrm{~h}$ per day and $35^{\circ} \mathrm{C} 12 \mathrm{~h}$ per day with $30-40 \%$ relative humidity. Feed and water intakes were recorded for HT ewes, and TN ewes were fed the average of HT ewe intake, as previously reported $(11,12)$. Animal care was approved by the University of Colorado Health Sciences Center Animal Care and Use Committee, protocol number 56304098 (06)-1F.

Tissue collection. Ewes were killed at either $56 \pm 1 \mathrm{dGA}, 93 \pm 1 \mathrm{dGA}$ or $135 \pm 1 \mathrm{dGA}$, corresponding to $16 \mathrm{~d}$ in treatment (dit; TN $n=6$, HT $n=6$ ), 53 dit (TN $n=8$, HT $n=6$ ) and 80 dit (TN $n=4$, HT $n=7$ ), respectively, as reported $(11,12)$. The 80 dit group were removed from the environmental chamber at $120 \mathrm{dGA}$, and maintained under TN conditions until autopsy at 135 dGA. At autopsy, fetal and placental weights were recorded as reported $(11,12)$, and placentomes were manually separated into fetal cotyledonary and maternal caruncular components.

Reverse transcriptase-polymerase chain reaction (RT-PCR) and cDNA preparation. Total cellular RNA (tcRNA) was isolated from ovine cotyledonary and caruncular tissue as previously described $(11,12)$, and resulting tcRNA concentration was determined by absorbance at $\mathrm{A}^{260}$.

Angiopoietin 1. Published sequences for human (Genbank accession number U83508) and mouse (U83509) Ang-1 were compared and conserved regions were selected as primers. The upper primer ( $5^{\prime}$-GGGAGGTTGGACTGTAAT- $3^{\prime}$ ) and lower primer ( $5^{\prime}$-CTTTATCCCATTCAGTTT-3') fell within the coding sequence, and coincided with 1272-1289 bp and 1717-1734 bp of the human Ang-1 sequence, respectively.

Reverse transcription (RT) was carried out using $1.0 \mu \mathrm{g}$ of tcRNA collected from $100 \mathrm{dGA}$ ovine cotyledonary tissue. The reaction mixture contained 1 $\mu \mathrm{M}$ of the lower Ang-1 specific primer, $0.01 \mathrm{mM}$ DTT, $2 \mathrm{mM}$ dNTP, 2.5 units of RNase inhibitor and 200 units of recombinant Moloney Murine Leukemia Virus reverse transcriptase (M-MLV RT) in a $20 \mu \mathrm{L}$ final volume $(75 \mathrm{mM}$ $\mathrm{KCl}, 3 \mathrm{mM} \mathrm{MgCl}{ }_{2}, 50 \mathrm{mM}$ Tris-HCl, $\mathrm{pH} 8.3$ ). Reactions were incubated for $1 \mathrm{~h}$ at $42^{\circ} \mathrm{C}$. Subsequent PCR was performed on $5 \mu \mathrm{L}$ of RT product in a mixture of $0.5 \mu \mathrm{M}$ of each Ang-1 specific primer, $2 \mathrm{mM} \mathrm{MgCl}_{2}, 0.2 \mathrm{mM}$ dNTP and 2.5 units of TaqDNA polymerase in a $50 \mu \mathrm{L}$ final volume $(50 \mathrm{mM} \mathrm{KCl}$, $20 \mathrm{mM}$ Tris-HCl, pH 8.4). PCR was conducted for 35 cycles at 94,61 and $72^{\circ} \mathrm{C} 1 \mathrm{~min}$ each with a final $10 \mathrm{~min}$ extension at $72^{\circ} \mathrm{C}$. The PCR product was inserted into $\mathrm{pCR} 2.1$ and transformed into Inv $\alpha \mathrm{F}^{\prime}$ competent cells as described by the manufacturer (Invitrogen Corporation, Carlsbad, CA). The insert was sequenced (Davis Sequencing, University of California, Davis, CA) in both directions to verify authenticity, compared with cattle (AF093573), human and mouse sequences, and the sequence, minus the primers, was deposited with Genbank (AY881028). This cDNA was used as PCR template, with new upper (5'-TTGCCATAACCAGTCAGAG- $\left.3^{\prime}\right)$ and lower (5'AACCACCAGCCTCCTGTTA-3') primers, to generate a 259 bp ovine Ang-1 cDNA which was inserted into pCR-Script ${ }^{\circledR}$ (Stratagene, La Jolla, CA), sequenced for authenticity, and used for generating real-time RT-PCR standards (see below).

Angiopoietin 2. Published sequences for human (AF004327) and mouse (AF004326) Ang-2 were compared and conserved regions were selected as primers. The upper primer $\left(5^{\prime}\right.$-GAAGAAAGAATGTGGCAGAT- $\left.3^{\prime}\right)$ fell just before the coding sequence $(341-360 \mathrm{bp})$ and the lower primer (5'GTCACATGAGGCCTTGATCTC- $3^{\prime}$ ) fell within the coding sequence (1271$1291 \mathrm{bp})$. The ovine Ang-2 cDNA was generated by RT-PCR using the same conditions as for Ang-1, subcloned into pCR2.1, sequenced, compared with cattle (AF094699), human and mouse sequences, and the sequence, minus the primers, was deposited with Genbank (AY881029). Sequence analysis revealed that the upper primer annealed to a homologous region (664-684 bp of AF004327) of Ang-2 mRNA, not the region from which the primer was designed, thereby yielding a $619 \mathrm{bp}$ cDNA (including the primers). This cDNA was used as PCR template, with new upper (5'-GACCGCTGTGATGATAGAA- $\left.3^{\prime}\right)$ and lower ( $5^{\prime}$-TTTGATTGACCCGAAGTTGA- $\left.3^{\prime}\right)$ primers, to generate a 269 bp ovine Ang-2 cDNA which was inserted into pCR-Script ${ }^{\circledR}$ (Stratagene, La Jolla, CA), sequenced for authenticity, and used for generating real-time RT-PCR standards (see below).

Tie-2. Primers were designed from the bovine Tie-2 sequence $(\times 71424)$. The upper ( $5^{\prime}$-GAGGACAGGCAATAAGGATAC- $\left.3^{\prime}\right)$ and lower primers $\left(5^{\prime}\right.$ GGAGACAGAACACGAAGGACT- $3^{\prime}$ ) were both located within the coding sequence (643-663 bp and 1147-1167 bp, respectively). Two $\mu \mathrm{g}$ of tcRNA collected from $100 \mathrm{dGA}$ ovine fetal brain served as the template for RT-PCR, under conditions similar to those described for Ang-1, with 35 cycles at 94, 60 and $72^{\circ} \mathrm{C}, 1 \mathrm{~min}$ each. The resulting cDNA was inserted into pCR-Script ${ }^{\circledR}$ (Stratagene, La Jolla, CA), sequenced in both directions (Macromolecular Resources, Colorado State University, Fort Collins, CO) to verify authenticity, compared with cattle, human (NM_000459) and mouse $(\times 71426)$ Tie-2 sequences, and the sequence, minus the primers, was deposited with Genbank (AY881030).

$\boldsymbol{\beta}$-actin. The 498 bp ovine $\beta$-actin cDNA used in these studies has already been described (11).

Real-time RT-PCR. Quantitative PCR was carried out using a Bio-Rad iCycler® (Hercules, California). PLATINUM Quantitative PCR SUPERMixUDG (1.5U PLATIMUM TaqDNA polymerase, $20 \mathrm{mM}$ Tris- $\mathrm{HCl}$ (pH 8.4), 50 $\mathrm{mM} \mathrm{KCl}, 3 \mathrm{mM} \mathrm{MgCl} 2,200 \mu \mathrm{M}$ dGTP, $200 \mu \mathrm{M}$ dATP, $200 \mu \mathrm{M}$ dCTP, 200 $\mu \mathrm{M}$ dUTP, 1U UDG) was the base for the master mix. To determine the optimum $\mathrm{MgCl}_{2}$ concentration for each amplicon, identical samples were amplified in the presence of either $3 \mathrm{mM}, 4 \mathrm{mM}, 5 \mathrm{mM}$ or $6 \mathrm{mM} \mathrm{MgCl}_{2}$. The $2 \times$ Platinum ${ }^{\circledR}$ Quantitative PCR SuperMix-UDG (GIBCO BRL®) contains a final $\mathrm{MgCl}_{2}$ concentration of $3 \mathrm{mM}$, and the reactions were adjusted accordingly with $50 \mathrm{mM} \mathrm{MgCl}$. The reaction closest to a line with the slope of -3.322 (which is considered $100 \%$ efficiency for the iCycler ${ }^{\circledR}$ ) was identified, and the corresponding $\mathrm{MgCl}_{2}$ concentration was used for that particular amplicon. The predetermined $\mathrm{MgCl}_{2}$ concentration was then added to the master mix of $0.2 \mu \mathrm{M}$ forward primer, $0.2 \mu \mathrm{M}$ reverse primer, $0.2 \mu \mathrm{M}$ SYBR® Green I (Molecular Probes, Eugene, OR), $2 \times$ Platinum ${ }^{\circledR}$ Quantitative PCR SuperMix-UDG (GIBCO BRL®) and volumed to $40 \mu \mathrm{L}$ with PCR grade $\mathrm{H}_{2} \mathrm{O}$ (Ambion Inc.).

To the seven standard reactions, $10 \mu \mathrm{L}$ of control template was added to 40 $\mu \mathrm{L}$ of master mix. To make the standards, a 10 -fold dilution series was prepared of sample template (Ang-1, Ang-2, Tie- 2 or $\beta$-actin cDNA) from 10 to $10^{-5} \mathrm{pg} / 10 \mu \mathrm{L}$. For the samples of unknown amplicon, $5 \mu \mathrm{L}$ RT (as described previously) and $5 \mu \mathrm{L}$ PCR grade $\mathrm{H}_{2} 0$ (Ambion Inc.) was added to 40 $\mu \mathrm{L}$ of master mix. When the RT reactions were prepared for either cotyledon or caruncle of each animal in all treatment groups, the quantity was adjusted to allow the same RT reaction to be used for Ang-1, Ang-2, Tie-2 and $\beta$-actin amplification.

Finally, $50 \mu \mathrm{L}$ reactions were mixed, and aliquoted into 96-well PCR plates (Bio-Rad). Before running each PCR reaction, an external Well Factor (BioRad) plate was used to calibrate the iCycler®, adjust for any imperfections in mirrors and collect background data. PCR conditions were 5 min at $95^{\circ} \mathrm{C}$ followed by 45 cycles of $20 \mathrm{~s}$ at $95^{\circ} \mathrm{C}, 1 \mathrm{~min}$ at optimal annealing temperature (Ang- $1,57^{\circ} \mathrm{C}$; Ang- $2,57^{\circ} \mathrm{C}$; Tie- $2,60^{\circ} \mathrm{C} ; \beta$-Actin, $55^{\circ} \mathrm{C}$ ), followed by $1 \mathrm{~min}$ at $72^{\circ} \mathrm{C}$. Fluorescent data were collected by the iCycler ${ }^{\circledR}$ during the optimal annealing step for real time analysis. Reproducibility of the real-time RT-PCR data were evaluated by determining an intra-assay coefficient of variation for a high, middle and low set of standards for each amplicon. The average correlation coefficients and slopes for each Ang-1, Ang-2, Tie- 2 and $\beta$-actin $\mathrm{PCR}$, as well as for all runs included in the data set, were compared with the correlation coefficient and slope representing $100 \%$ efficiency for the iCycler ${ }^{\circledR}$ as determined by BioRad $\AA$ and expressed as mean \pm SEM.

Southern blot analysis. Real-time RT-PCR products were electrophoresed through 1\% Agarose gels and capillary blotted onto nylon membranes. Asymmetric PCR was used to generate dCTP- ${ }^{32} \mathrm{P}$ labeled cDNAs encoding Ang-1, Ang-2, Tie- 2 and $\beta$-actin. The denatured, PCR generated cDNA was added to 
membranes at a concentration of $2-4 \times 10^{6} \mathrm{cpm} / \mathrm{mL}$ and incubated overnight at $42^{\circ} \mathrm{C}$. Membranes were then washed and exposed to Kodak x-ray film to verify hybridization of real-time RT-PCR product.

Protein extraction and western blot analysis. Tris-based lysis buffer $(0.48$ M Tris (pH 7.4), $10 \mathrm{mM}$ EGTA, $10 \mathrm{mM}$ EDTA, $0.1 \%$ vol/vol BME, Protease/ phosphatase Inhibitor cocktail (Sigma Chemical Co.), $0.1 \mathrm{mM}$ AEBSF, 2.0 $\mu \mathrm{M}$ Leupeptin, 1.5 $\mu \mathrm{M}$ Pepstatin, $1.4 \mu \mathrm{M}$ E64, 4.0 $\mu \mathrm{M}$ Bestatin, $0.08 \mu \mathrm{M}$ Aprotinin, $0.1 \mathrm{mM}$ PMSF) was added to $100 \mathrm{mg}$ of either cotyledonary or caruncular tissue, sonicated, and the resulting protein concentration was quantified by Bradford assay. Proteins were separated using $10 \%$ Tris-HCl gels (BioRad) for Ang-1 and Ang-2, or 7.5\% Tris-HCl gels Tie-2, and subjected to Western Blot analysis as previously described $(11,12)$. Detection of Ang-1 (sc-6320), Ang-2 (sc-7015), Tie-2 (sc-324) and Actin (sc-1615) was accomplished by incubating in the presence of a 1:1000 dilution of primary antiserum (Santa Cruz Biotechnology), followed by incubation with anti-goat IgG (Ang-1, Ang-2 and Actin) or anti-rabbit IgG (Tie-2) horseradish peroxidase conjugated secondary antibody (Santa Cruz Biotechnology) at 1:20,000. Following incubation in Supersignal West Femto Maximum Sensitivity Substrate (Pierce Chemical Co., Rockford, IL), the membranes were exposed to Kodak $\mathrm{x}$-ray film. Protein quantification was accomplished using ImageQuant (Molecular Dynamics). Specific blocking peptides (Santa Cruz Biotechnology) were used to verify authenticity of detection.

Statistical analysis. Concentrations of Ang-1, Ang-2 and Tie-2 mRNA and protein were normalized on the respective $\beta$-actin concentration, and normalacy of the data were tested with a two-tailed F test. Between treatment comparisons for either cotyledonary or caruncular tissue within the same gestational age (day $55 \mathrm{TN}$ vs. day $55 \mathrm{HT}$, day $90 \mathrm{TN}$ vs. day $90 \mathrm{HT}$, and day $135 \mathrm{TN}$ vs. day $135 \mathrm{HT}$ ) were compared by Student's $t$ test, and are presented as mean \pm SEM. A $p$-value $\leq 0.05$ was considered statistically significant.

\section{RESULTS}

Generation of Ovine cDNAs. Using RT-PCR, partial cDNAs for ovine Ang-1, Ang-2 and Tie-2 were generated and sequenced. The 427 bp ovine Ang-1 sequence exhibited 98, 92 and $88 \%$ sequence identity with cattle, human and mouse Ang- 1 sequences, respectively. The 578 bp ovine Ang- 2 cDNA shared 94,85 and $79 \%$ nucleotide sequence identity with cattle, human and mouse Ang-2, respectively, and the ovine Tie-2 (483 bp) sequence exhibited 97, 92 and $89 \%$ sequence identity with cattle, human and mouse Tie-2.

Real-time $\boldsymbol{R} \boldsymbol{T}$-PCR . Utilizing these cDNAs, mRNA expression was evaluated in 55, 90 and $135 \mathrm{dGA}$ placental tissue by real-time RT-PCR. The placental and fetal characteristics of these pregnancies have been previously reported $(11,12)$. There was a $36 \%$ reduction in placental weight and a $27 \%$ reduction in fetal weight at $90 \mathrm{dGA}$ gestational age (11), and reductions of placental and fetal weights (12) of approximately $51 \%$ and $42 \%$, respectively, at $135 \mathrm{dGA}$. The intra-assay coefficient of variation for Ang-1, Ang-2, Tie-2 and $\beta$-actin mRNA determinations by real-time RT-PCR was $1.94 \%, 1.23 \%, 1.64 \%$ and $1.28 \%$ respectively. Expression of Ang-1 in the maternal caruncle was not significantly $(p \geq 0.10)$ affected by treatment, at any of the gestational ages examined (Fig. 1). However, Ang-1 mRNA concentration was significantly $(p \leq 0.05)$ increased at 55 dGA in HT fetal cotyledons, but remained unchanged ( $p \geq$ 0.10 ) at 90 and $135 \mathrm{dGA}$ (Fig. 1). Angiopoietin-2 mRNA showed a similar expression pattern as Ang-1 mRNA, with no effect $(p \geq 0.10)$ of treatment at any gestational age in the maternal caruncle, but a significant $(p \leq 0.05)$ increase in 55 dGA fetal cotyledons from HT pregnancies (Fig. 2). Real-time RT-PCR analysis of maternal caruncular tissue for Tie-2 revealed that mRNA concentration was significantly $(p \leq 0.05)$ decreased at 135 dGA in HT pregnancies, but there were no significant $(p \geq$ 0.10 ) changes at 55 or $90 \mathrm{dGA}$ due to treatment (Fig. 3). However, Tie- 2 mRNA concentration was significantly $(p \leq 0.01)$ increased
A

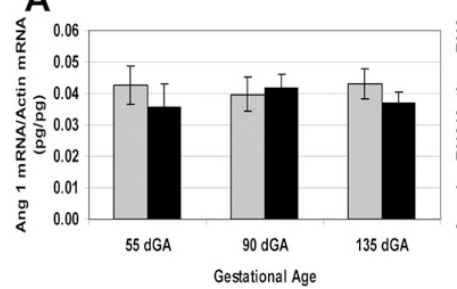

B

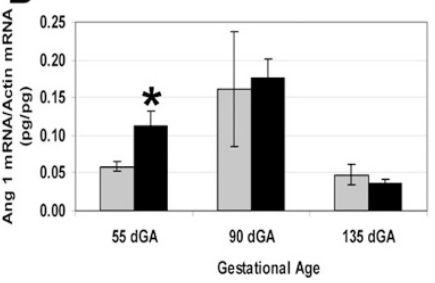

Figure 1. Relative concentrations of ovine Ang-1 mRNA at 55, 90 and $135 \mathrm{~d}$ of gestation in an ovine model of FGR. Ovine Ang-1 mRNA concentrations in the maternal caruncle $(A)$ and fetal cotyledon $(B)$, were determined by realtime RT-PCR and normalized on $\beta$-actin mRNA concentrations, for both TN (shaded columns) and HT (black columns) pregnancies at 55 (TN $n=6$, HT $n=6), 90$ (TN $n=8$, HT $n=6$ ) and 135 (TN $n=4$, HT $n=7)$ dGA. ${ }^{*} p$ $\leq 0.05$, comparison between $\mathrm{TN}$ and $\mathrm{HT}$, within gestational age.
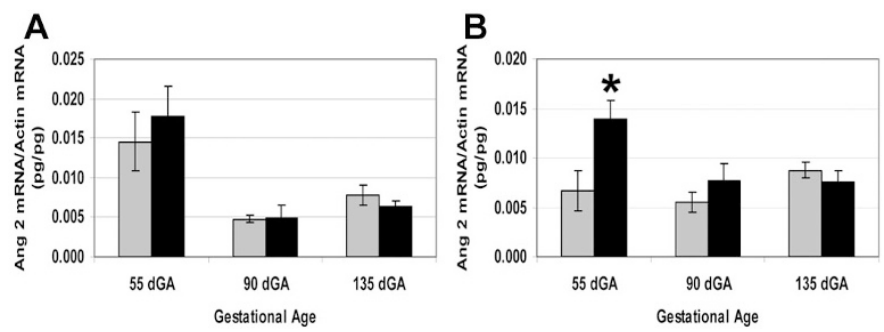

Figure 2. Relative concentrations of ovine Ang-2 mRNA at 55, 90 and $135 \mathrm{~d}$ of gestation in an ovine model of FGR. Ovine Ang-2 mRNA concentrations in the maternal caruncle $(A)$ and fetal cotyledon $(B)$, were determined by realtime RT-PCR and normalized on $\beta$-actin mRNA concentrations, for both TN (shaded columns) and HT (black columns) pregnancies at 55 (TN $n=6$, HT $n=6), 90$ (TN $n=8$, HT $n=6$ ) and 135 (TN $n=4$, HT $n=7$ ) dGA. * $p$ $\leq 0.05$, comparison between TN and HT, within gestational age.
A

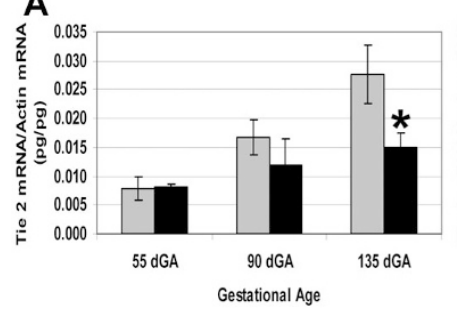

B

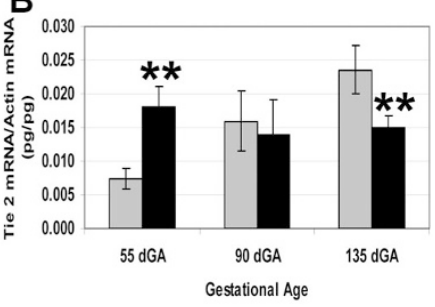

Figure 3. Relative concentrations of ovine Tie-2 mRNA at 55, 90 and $135 \mathrm{~d}$ of gestation in an ovine model of FGR. Ovine Tie- 2 mRNA concentrations in the maternal caruncle $(A)$ and fetal cotyledon $(B)$, were determined by realtime RT-PCR and normalized on $\beta$-actin mRNA concentrations, for both TN (shaded columns) and HT (black columns) pregnancies at 55 (TN $n=6$, HT $n=6), 90$ (TN $n=8$, HT $n=6)$ and 135 (TN $n=4$, HT $n=7)$ dGA. * $p$ $\leq 0.05 ; * * p \leq 0.01$, comparison between TN and HT, within gestational age.

at $55 \mathrm{dGA}$ and significantly $(p \leq 0.01)$ depressed at $135 \mathrm{dGA}$ in fetal cotyledons from HT pregnancies, but was unaffected by treatment at $90 \mathrm{dGA}$ (Fig. 3).

Western blot analysis. Tissue protein concentrations of Ang-1, Ang-2 and Tie-2 were determined in ovine placental tissue at 55, 90 and $135 \mathrm{dGA}$ for both treatments, and the data were normalized on $\beta$-actin concentrations. Single bands were detected for each protein with the antibodies used, and their authenticity verified by preincubation with blocking peptides. Ang-1 and Ang-2 had apparent molecular weights of approximately 55,000 (Fig. 4 and 5), whereas the apparent molecular weight of Tie-2 was approximately 150,000 (Fig. 6). Tissue concentrations of ovine Ang-1 were not significantly ( $p \geq$ 

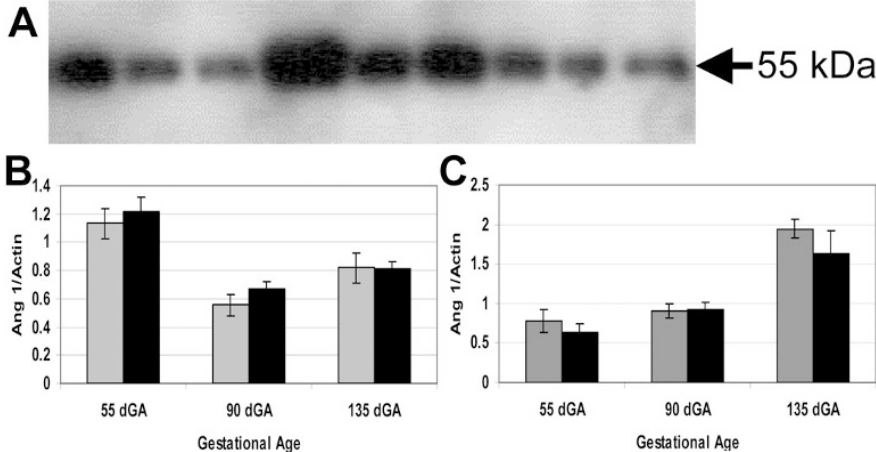

Figure 4. Relative concentrations of ovine Ang-1 at 55, 90 and $135 \mathrm{~d}$ of gestation in an ovine model of FGR. A representative Western blot for Ang-1for $135 \mathrm{dGA}$ cotyledon samples is presented in the top panel (A) along with the apparent molecular weight of the immunoreactive bands. Ovine Ang-1 concentrations in the maternal caruncle $(B)$ and fetal cotyledon $(C)$, were determined by Western blot analysis and normalized on $\beta$-actin concentrations, for both TN (shaded columns) and HT (black columns) pregnancies at 55 (TN $n=6$, HT $n=6$ ), 90 (TN $n=8$, HT $n=6$ ) and 135 (TN $n=4$, HT $n=7$ ) dGA. No statistical differences were found.

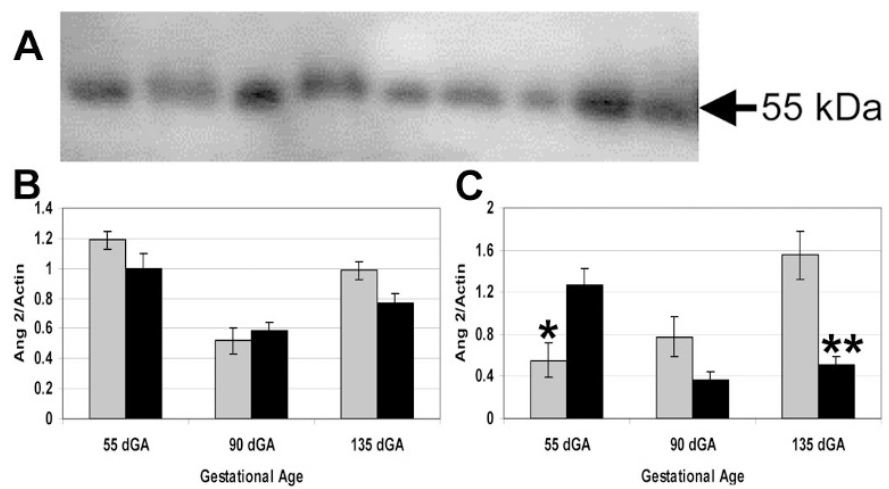

Figure 5. Relative concentrations of ovine Ang-2 at 55, 90 and $135 \mathrm{~d}$ of gestation in an ovine model of FGR. A representative Western blot for Ang-2 for $135 \mathrm{dGA}$ cotyledon samples is presented in the top panel $(A)$ along with the apparent molecular weight of the immunoreactive bands. Ovine Ang- 2 concentrations in the maternal caruncle $(B)$ and fetal cotyledon $(C)$, were determined by Western blot analysis and normalized on $\beta$-actin concentrations, for both TN (shaded columns) and HT (black columns) pregnancies at 55 (TN $n=6$, HT $n=6$ ), 90 (TN $n=$ 8 , HT $n=6$ ) and 135 (TN $n=4$, HT $n=7)$ dGA. * $p \leq 0.05$, ** $p \leq 0.01$, comparison between TN and HT, within gestational age.

$0.10)$ affected by treatment or tissue type at any gestational age (Fig. 4). However, ovine Ang-2 concentration tended ( $p \leq$ 0.10 ) to be lower in HT caruncular tissue at 135 dGA (Fig. 5). In the fetal cotyledon, concentration of Ang-2 was increased at $55 \mathrm{dGA}(p \leq 0.05)$, but tended $(p \leq 0.10)$ to be lower at 90 $\mathrm{dGA}$, and was significantly less in $135 \mathrm{dGA}(p \leq 0.01)$ HT fetal cotyledons (Fig. 5). Tie-2 concentration was not significantly altered at $55 \mathrm{dGA}$ in the maternal caruncle, but was significantly increased $(p \leq 0.05)$ at $90 \mathrm{dGA}$ and tended $(p \leq$ 0.10 ) to be less in $135 \mathrm{dGA}$ HT pregnancies (Fig. 6). Fetal cotyledon Tie- 2 concentration was not significantly altered by treatment at any gestational age (Fig. 6).

\section{DISCUSSION}

Placental development begins early in pregnancy, and continues throughout gestation, as increased blood supply to, and vascular development within, the placentas are required to

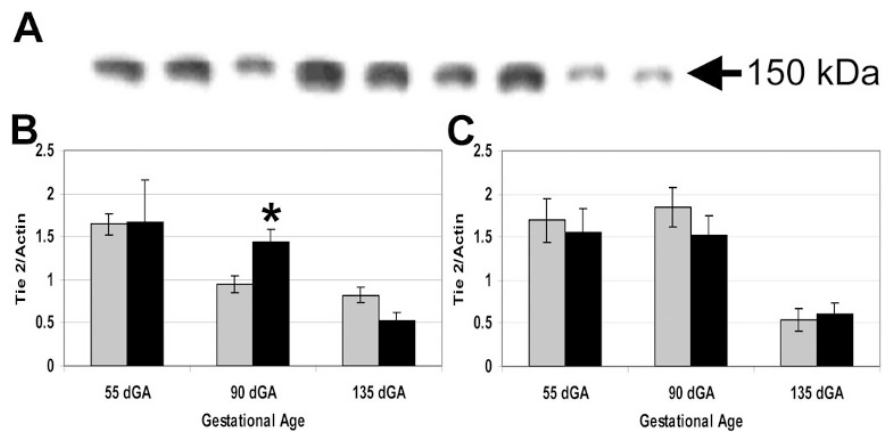

Figure 6. Relative concentrations of ovine Tie- 2 at 55, 90 and $135 \mathrm{~d}$ of gestation in an ovine model of FGR. A representative Western blot for Tie-2 for $135 \mathrm{dGA}$ cotyledon samples is presented in the top panel along with the apparent molecular weight of the immunoreactive bands. Ovine Tie-2 concentrations in the maternal caruncle $(B)$ and fetal cotyledon $(C)$, were determined by Western blot analysis and normalized on $\beta$-actin concentrations, for both TN (shaded columns) and HT (black columns) pregnancies at 55 (TN $n=6$, HT $n=6$ ), 90 (TN $n=8$, HT $n=6$ ) and 135 (TN $n=4$, HT $n=7$ ) dGA. $* p \leq 0.05$, comparison between TN and HT, within gestational age.

support the needs of the growing fetus. The importance of these processes becomes obvious when placental development is perturbed, leading to functional placental insufficiency and FGR. In the present study, we examined placental expression of Ang-1, Ang-2 and Tie-2 in an ovine model of FGR that results from placental growth restriction (11-13). At $55 \mathrm{dGA}$, Ang-1, Ang-2 and Tie-2 mRNA concentrations were elevated in the fetal cotyledon, but only Ang-2 protein concentration was increased and there were no expression differences in the maternal caruncle. These data agree with our previous report (11) of increased VEGF mRNA at 55 dGA in FGR pregnancies, and may be a function of altered blood flow in response to the hyperthermic environment. Uteroplacental blood flow has been reported to fall following exposure to hyperthermia during mid-pregnancy ( $80 \mathrm{dGA})$, and persisted throughout the $20 \mathrm{~d}$ treatment period (17), potentially generating a hypoxic environment for placental development. However, potential changes in uteroplacental blood flow and oxygen uptake have not been evaluated using our current paradigm. Elevated expression of VEGF (11), Ang-1, Ang-2 and Tie-2 may be an adaptive response to this environment, in an attempt to maintain placental development, but may also adversely program the placenta for functional insufficiency later in gestation, by altering the trajectory or pattern of placental vascular development. At $90 \mathrm{dGA}$, the only significant change in expression occurred with Tie-2, and while Tie- 2 protein concentration was elevated in the maternal caruncle, no differences were found in maternal caruncle Tie- 2 mRNA concentration or in fetal cotyledon mRNA or protein concentration. It is interesting to note that at this stage of gestation, fetal cotyledon PIGF, VEGFR-1 and VEGFR-2 mRNA concentrations are reduced (11). While the significance of these changes is not easily discernible, they may indicate that this is a period of transition toward the end of the second third of gestation between the acute responses and those observed with late gestational placental insufficiency.

Near-term (135 dGA), we observed reductions in Tie-2 mRNA concentration within the maternal caruncle and fetal cotyledon, as well as reduced Ang-2 protein concentrations in the 
fetal cotyledon with no statistical differences in mRNA concentration. The Ang-2 data agree with the report by Dunk et al. (18) with human FGR pregnancies, characterized by absent end diastolic umbilical flow velocities, in that placental Ang2 concentration is depressed without coordinate reductions in Ang2 mRNA. Dunk et al. (18) suggest that this may result from a failure of translational regulatory mechanism in these FGR pregnancies. Previously we reported reduced VEGF mRNA and protein concentrations and reduced VEGFR-1 mRNA concentration in the fetal cotyledon of $135 \mathrm{dGA}$ FGR pregnancies, whereas maternal caruncle PIGF mRNA and protein were elevated (12). Hypoxia is known to stimulate VEGF expression (19), and both hypoxia and VEGF stimulate Ang-2 expression (20). While the near-term fetuses in our study were hypoxic (12), maternal uterine blood flow and uterine venous $\mathrm{P}_{\mathrm{O} 2}$ were increased, leading to a greater transplacental $\mathrm{P}_{\mathrm{O} 2}$ gradient, consistent with the concept of postplacental hypoxia (21) in severe FGR.

Development of the placental vascular network begins early, with an initial phase of vasculogenesis, followed by branching and then nonbranching angiogenesis (22). Whereas VEGF promotes both vasculogenesis and angiogenesis within the placenta (23), the angiopoietins likely only play a role in angiogenesis (24). Both Ang-1 and Ang-2 interact with the receptor Tie-2 (14) with equal affinity, and while Ang-1 induces maturation and stabilization of the developing vasculature (25), Ang-2 causes destabilization required for additional sprout formation and branching angiogenesis (14).

Within the human placenta, Ang-2 expression is greatest during the first trimester, and wanes as gestation progresses $(26,27)$. Greater expression of Ang-2 during the first trimester, with Ang-1 and VEGF expression increasing from early to late gestation (27), fits with the concept that branching angiogenesis occurs during early placental development, followed by nonbranching angiogenesis (22). In the present study, the reductions in Ang-2 and Tie-2 coincide with reductions in VEGF and VEGFR-1 along with elevated PIGF (12), suggesting a disposition toward increased nonbranching angiogenesis in our near-term FGR pregnancies.

With the current data for the angiopoietins and their receptor, our earlier studies of VEGF, PlGF and their receptors $(11,12)$, along with reports by others $(18)$, discordance between tissue mRNA and protein concentrations is observed. These apparent discordant responses may well result from singlepoint in time measurements, or the fact that when measuring tissue concentrations of a protein, one cannot discern between intracellular stores, protein associated with extracellular matrix or specific receptors, or determine the degradation rate following receptor binding. It is possible that posttranscriptional regulation of all of these angiogenic growth factors and their receptors, such as has been documented for $\operatorname{VEGF}(28,29)$ could explain these discrepancies. Regardless, these data clearly define that changes in angiogenic growth factor expression during the first two-thirds of gestation is quite different from those observed near-term. The early changes may well occur as a compensatory mechanism, but in turn set the stage for increased nonbranching angiogenesis, altered placental architecture and functional placental insufficiency that result in FGR during late gestation.

\section{REFERENCES}

1. Lee MM, Yeh MN 1986 Fetal microcirculation of abnormal human placenta. I. Scanning electron microscopy of placental vascular casts from small for gestational age fetus. Am J Obstet Gynecol 154:1133-1139

2. Salafia CM, Pezzullo JC, Minior VK, Divon MY 1997 Placental pathology of absent and reversed end-diastolic flow in growth-restricted fetuses. Obstet Gynecol 90:830 836

3. Giles WB, Trudinger BJ, Baird PJ 1985 Fetal umbilical artery flow velocity waveforms and placental resistance: pathological correlation. $\mathrm{Br} \mathrm{J}$ Obstet Gynaecol 92:31-38

4. Krebs C, Macara LM, Leiser R, Bowman AW, Greer IA, Kingdom JC 1996 Intrauterine growth restriction with absent end-diastolic flow velocity in the umbilical artery is associated with maldevelopment of the placental terminal villous tree. Am J Obstet Gynecol 175:1534-1542

5. Macara L, Kingdom JC, Kaufmann P, Kohnen G, Hair J, More IA, Lyall F, Greer IA 1996 Structural analysis of placental terminal villi from growth-restricted pregnancies with abnormal umbilical artery Doppler waveforms. Placenta 17:37-48

6. Mayhew TM, Ohadike C, Baker PN, Crocker IP, Mitchell C, Ong SS 2003 Stereological investigation of placental morphology in pregnancies complicated by pre-eclampsia with and without intrauterine growth restriction. Placenta 24:219-226

7. Ahmed A, Perkins J 2000 Angiogenesis and intrauterine growth restriction. Baillieres Best Pract Res Clin Obstet Gynaecol 14:981-998

8. Anthony RV, Scheaffer AN, Wright CD, Regnault TR 2003 Ruminant models of prenatal growth restriction. Reprod Suppl 61:183-194

9. Kaufmann P 1982 Development and differentiation of the human villous tree. Bibl Anat 22:29-39

10. Leiser R, Krebs C, Ebert B, Dantzer V 1997 Placental vascular corrosion cast studies: a comparison between ruminants and humans. Microsc Res Tech 38:76-87

11. Regnault TR, Orbus RJ, de Vrijer B, Davidsen ML, Galan HL, Wilkening RB, Anthony RV 2002 Placental expression of VEGF, PlGF and their receptors in a model of placental insufficiency-intrauterine growth restriction (PI-IUGR). Placenta 23:132144

12. Regnault TR, de Vrijer B, Galan HL, Davidsen ML, Trembler KA, Battaglia FC, Wilkening RB, Anthony RV 2003 The relationship between transplacental $\mathrm{O}_{2}$ diffusion and placental expression of PlGF, VEGF and their receptors in a placental insufficiency model of fetal growth restriction. J Physiol 550:641-656

13. Galan HL, Anthony RV, Rigano S, Parker TA, de Vrijer B, Ferrazzi E, Wilkening RB, Regnault TR 2005 Fetal hypertension and abnormal Doppler velocimetry in an ovine model of intrauterine growth restriction. Am J Obstet Gynecol 192:272-279

14. Maisonpierre PC, Suri C, Jones PF, Bartunkova S, Wiegand SJ, Radziejewski C, Compton D, McClain J, Aldrich TH, Papadopoulos N, Daly TJ, Davis S, Sato TN, Yancopoulos GD 1997 Angiopoietin-2, a natural antagonist for Tie2 that disrupts in vivo angiogenesis. Science 277:55-60

15. Koblizek TI, Weiss C, Yancopoulos GD, Deutsch U, Risau W 1998 Angiopoietin-1 induces sprouting angiogenesis in vitro. Curr Biol 8:529-532

16. Suri C, Jones PF, Patan S, Bartunkova S, Maisonpierre PC, Davis S, Soto TN, Yancopoulos GD 1996 Requisite role of angiopoietin-1, a ligand for the Tie2 receptor, during embryonic angiogenesis. Cell 87:1171-1180

17. Alexander G, Hales JR, Stevens D, Donnelly JB 1987 Effects of acute and prolonged exposure to heat on regional blood flows in pregnant sheep. J Dev Physiol 9:1-15

18. Dunk C, Shams M, Nijjar S, Rhaman M, Qiu Y, Bussolati B, Ahmed A 2000 Angiopoietin-1 and angiopoietin-2 activate trophoblast Tie-2 to promote growth and migration during placental development. Am J Pathol 156:2185-2199

19. Schweiki D, Itin A, Soffer D, Keshet E 1992 Vascular endothelial growth factor induced by hypoxia may mediate hypoxia-initiated angiogenesis. Nature 359:843845

20. Oh H, Takagi H, Suzuma K, Otani A, Matsumura M, Honda Y 1999 Hypoxia and vascular endothelial growth factor selectively up-regulate angiopoietin-2 in bovine microvascular endothelial cells. J Biol Chem 274:15732-15739

21. Kingdom JC, Kaufmann P 1997 Oxygen and placental villous development:-origins of fetal hypoxia. Placenta 18:613-621

22. Benirschke K, Kaufmann P 2000 Pathology of the Human Placenta. Springer, New York, pp 116-154.

23. Ferrara N 2000 Vascular endothelial growth factor and the regulation of angiogenesis. Recent Prog Horm Res 55:15-35

24. Carmeliet P 2000 Mechanisms of angiogenesis and arteriogenesis. Nat Med 6:389_ 395

25. Asahara T, Chen D, Takahashi T, Fujikawa K, Kearney M, Magner M, Yancopoulos GD, Isner JM 1998 Tie2 receptor ligands, angiopoietin-1 and angiopoietin-2, modulate VEGF-induced postnatal neovascularization. Circ Res. 83:233-240

26. Goldman-Wohl DS, Ariel I, Greenfield C, Lavy Y, Yagel S 2000 Tie-2 and angiopoietin-2 expression at the fetal-maternal interface: a receptor ligand model for vascular remodeling. Mol Hum Reprod 6:81-87

27. Geva E, Ginzinger DG, Zaloudek CJ, Moore DH, Byrne A, Jaffe RB 2002 Human placental vascular development: vasculogenic and angiogenic (branching and nonbranching) transformation is regulated by vascular endothelial growth factor-A, angiopoietin-1, and angiopoietin-2. J Clin Endoocrinol Metabol 87:4213-4224

28. Levy NS, Chung S, Furneaux H, Levy AP 1998 Hypoxic stabilization of vascular endothelial growth factor mRNA by the RNA-binding protein HuR. J Biol Chem 273:6417-6423

29. Shih SC, Claffey KP 1999 Regulation of human vascular endothelial growth factor mRNA stability in hypoxia by heterogeneous nuclear ribonucleoprotein L. J Biol Chem 274:1359-1365 